九州大学学術情報リポジトリ

Kyushu University Institutional Repository

\title{
Enhancement of Biodegradability of Paperboard in Soil by Supporting Trichoderma Cells and Nutritional Constituents
}

Mori, Masatsugu

Laboratory of Soil Biology \& Biochemistry, Division of Soil Science \& Plant Production, Department of Plant Resources, Agriculture, Kyushu University

Iwami, Yuko

Department of Applied Chemistry, Faculty of Engineering, Oita University

Sakai, Kenji

Laboratory of Soil Biology \& Biochemistry, Division of Soil Science \& Plant Production, Department of Plant Resources, Agriculture, Kyushu University

https://doi.org/10.5109/17809

出版情報：九州大学大学院農学研究院紀要. 55 (1)，pp.97-99，2010-02-26. Faculty of Agriculture， Kyushu University

バージョン :

権利関係 : 


\title{
Enhancement of Biodegradability of Paperboard in Soil by Supporting Trichoderma Cells and Nutritional Constituents
}

\author{
Masatsugu MORI ${ }^{1}$, Yuko IWAMI ${ }^{2}$ and Kenji SAKAI ${ }^{1 *}$ \\ Laboratory of Soil Biology \& Biochemistry, Division of Soil Science \& Plant Production, \\ Department of Plant Resources, Agriculture, Kyushu University, \\ Fukuoka 812-8581, Japan \\ (Received October 30, 2009 and accepted November 19, 2009)
}

\begin{abstract}
When paperboard made from used paper was supported by Trichoderma reesei NBRC31137, a cellulolytic basidiomyces, the weight decrease of the paperboard in soil was enhanced. Number of viable microorganisms around the paperboard in the soil increased and reached $10^{7}$ after 2 weeks. Nutritional medium by itself, constituted of yeast extract and peptone, also stimulated the degradation in soil. Cells of T. viride NBRC31326 and Trichoderma reesei NBRC 31327 were less effective. These results suggested that we could control biodegradation rare of cellulosic material in an agricultural field.
\end{abstract}

\section{INTRODUCTION}

Many kinds of fibers and polymers especially those from petroleum have been used as one-way plastic: plastic items once used have been immediately discarded as refuse. And recycle of such materials were generally in consideration for establishing 'Recycle-Based Society' in Japan (http://law.e-gov.go.jp/htmldata/H12/ H12HO110. html). To whatever they were intended to recycle, however, their collection and treatment (processing) require certain energy input, i.e. fossil fuel consumption. Especially, recycle of such materials in agriculture was badly evaluated in their Life Cycle Assessment (LCA) (Tan and Khoo, 2005). Reuse and recycle of these materials requires many steps for chemical transformation and reproduction of products. Furthermore, as they have been inevitably soiled during their usage and sometimes distributed in wide area, repetitive usage of plastic materials in agricultural field, such as transplantation pots, sometimes requires rather higher energy, i.e., fossil fuel, to collect and wash than making the new ones from virgin petroleum. Thus it is sometimes better to recycle them thermally than to reuse or recycle materially (Consonni et al., 2005).

In such situation, intentional operation of biodegradable bio-based materials, that would be degraded to carbon dioxide and water after their usage and mineralized in soil would be preferable rather than returning to reproduction cycle. Biodegradable natural fibers such as cellulose and bio-based plastics such as poly-L-lactate are recognized as environmentally-friendly materials, because carbon atoms in their molecule have been fixed by plant before harvest, net generation of carbon dioxide occurred by their mineralization would be zero, even if they incinerated or landfilled after usage (carbon neutral) (Sakai et al., 2003). Hence it would reduce energy cost for mate-

\footnotetext{
Laboratory of Soil Biology \& Biochemistry, Division of Soil Science \& Plant Production, Department of Plant Resources, Agriculture, Kyushu University, Fukuoka 812-8581, Japan

2 Department of Applied Chemistry, Faculty of Engineering, Oita University, 700 Dannoharu, Oita 870-1192, Japan

* Corresponding author (E-mail: kensak@agr.kyushu-u.ac.jp)
}

rial recycle and help for environmental protection (Sakai et al., 2001). In spite of that, their biodegradation rate are sometimes slow. Such biodegradable materials should be required to maintain functions, i.e., their shape and strength, during certain period in their usage, and should be degraded quickly after finishing their initial role. So that biodegradability of such materials have to be controlled and sometimes enhanced should begin being mineralized in the soil. To solve the above problems, we tried to introduce the timely-biodegradable characteristic to paperboard, by supporting cell suspensions of cellulolytic basidiomyces (Wyk and Mohulatsi,2003, Lo et al., 2005) with nutritional components for the growth of microorganism in soil (Gaint et al., 2005).

\section{MTERIALS \& METHODS}

Three kinds of bacidiomyces, Trichoderma viride NBRC31326, Trichoderma reesei NBRC31327, Trichoderma reesei NBRC31137 were obtained from NITE Biological Resource Center (Chiba, Japan). They were cultured in $1000 \mathrm{ml}$ yeast extract-peptone medium ( $0.3 \%$ yeast extract, $0.5 \%$ peptone, $\mathrm{pH} 6.5$; YP medium) with adding $1 \%$ cellulose at $30^{\circ} \mathrm{C}$ for $24 \mathrm{hs}$, with shaking at $120 \mathrm{rpm}$. After being harvested by centrifugation (8,000 $\times \mathrm{g}, 20 \mathrm{~min})$, the cells were washed with and suspended to fresh YP medium ( $0.5 \mathrm{mg}$ wet cells $/ \mathrm{ml})$. To support cells on the paperboard, the cell suspension $(10 \mathrm{ml})$ was immersed onto a paperboard sample $(2 \times 70$ $\times 40 \mathrm{~mm}$, ca $8 \mathrm{~g}, 4$ pieces in each experimental run). Then the paperboard were dried in a desiccator at room temparature for 3 days. After measuring the dry weight, the dried paperboard was put and keep between stainless nets $(8 \mathrm{~mm}$ mesh), and the nets with paperboard samples were laid in the soil $(2-4 \mathrm{~cm}$ depth). As a control, paperboard soaked into water or YP medium without cells was also laid under ground. Sample soil for gardening was commercially purchased, and stands at room temperature with sprinkling periodically (every 3 days). During thee experiment, the room temperature ranged $18{ }^{\circ} \mathrm{C}-28{ }^{\circ} \mathrm{C}$. Paperboard made from $100 \%$ used-newspaper was obtained from Nippon Seishi Co. (Oita, Japan). 
Two pieces of paperboards in each experimental runs were dig up after 2 and 4 weeks, and their surfaces were washed gently. After drying up at room temperature in a desiccator for 3 days, the stainless nets were taken off and the morphology and surface condition of samples were recorded and changes in dry weights of paperboard were measured. Soil samples attached on the paperboard surface (ca $0.5 \mathrm{~g}$ ) were collected, and microflora in the soil samples were analyzed: after diluting appropriately with saline, the samples $(0.1 \mathrm{ml})$ were spread out onto standard agar plates. Number of colonies appeared were counted after incubation of the plate at $30^{\circ} \mathrm{C}$ for 2 days.

\section{RESULTS \& DISCUSSION}

After 2 weeks incubation in soil, surface of all buried paperboards became rougher configuration, (errosion, and cracking), and changed their color to spotty of black and brown. Surface of samples supported by Trichoderma cells were slightly whitish by their grown hyphae. These changes were more significant after 4 weeks than after 2 weeks. Figure 1 shows change in dry weight of the paperboard during incubation in soil. Even in control run (without microorganism nor nutrition), linear weight loss of the paperboard was observed and the decrease was 5\% after 4 weeks. Support of YP medium alone slightly enhanced the degradation rate

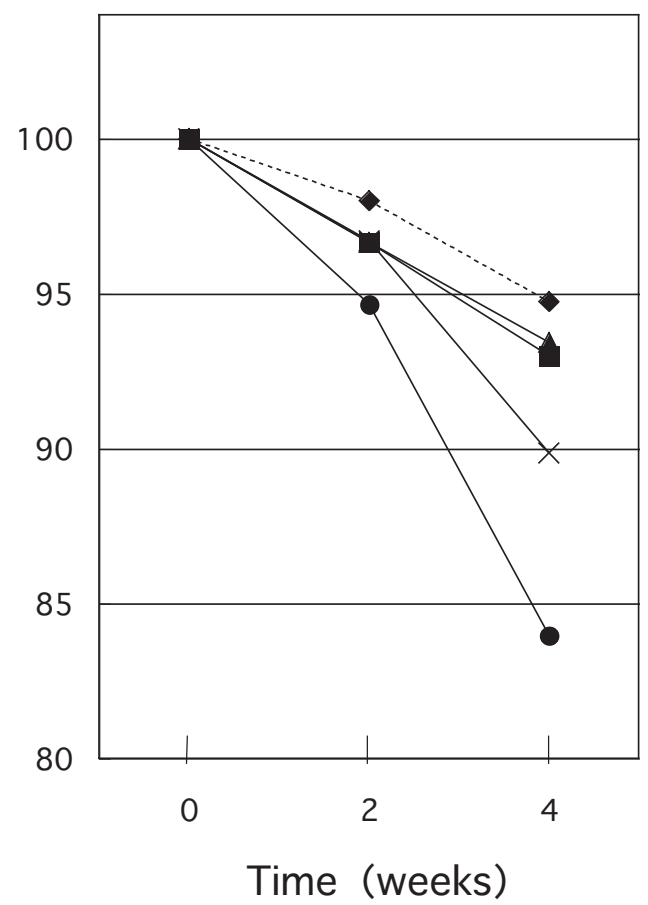

Fig. 1. Change in dry weight of paperboard buried in soil. Paperboard was soaked with water (diamond), $10 \mathrm{ml}$ YP medium (square), YP medium containing $500 \mathrm{mg}$ cells of T. viride NBRC 31326 (triangle), T, reesei NBRC 31137 (circle), or of T. reesei NBRC 31327 (cross), and after drying they were buried in soil for 2 or 4 weeks. Dry weight of paperboard samples (\%) are represented relatively to those before buried.
Table 1. Cell numbers in soil burying paperboard with YP medium constituents and Trichoderma cells

\begin{tabular}{lcc}
\hline \multirow{2}{*}{ Immersed with } & \multicolumn{2}{c}{ Cell number $\left(\times 10^{5}\right.$ cells/g $)$} \\
\cline { 2 - 3 } & After 2 weeks & After 4 weeks \\
\hline Water & $2.5 \pm 1.1$ & $29 \pm 0.7$ \\
YP medium & $42 \pm 2.3$ & $43 \pm 6.8$ \\
T. viride NBRC31326 & $68 \pm 12$ & $39 \pm 3.6$ \\
T. reesei NBRC31327 & $108 \pm 15$ & $45 \pm 2.9$ \\
T. reesei NBRC31137 & $110 \pm 17$ & $44 \pm 7.8$ \\
\hline
\end{tabular}

(7.2\% decrease after 4 weeks). Most significant degradation was observed in the sample supported by $T$. reese $i$ NBRC31137 with YP medium. Weight loss of the sample was accelerated during incubation in soil $(5.5 \%$ and $16.5 \%$, after 2 and 4 weeks, respectively). Support of $T$. reese $i$ NBRC31327 cells was less effective than the strain NBRC31137, and that of T. reesei NBRC31326 scarcely stimulated the degradation.

Concentrations of viable cells in the soil around the buried paperboard after 2 - and 4 -weeks were shown in Table 1. After 2 weeks, the soil around the paperboard immersed into YP medium contained 17-times higher concentrations of bacterial cells, compared with soil in control run (no medium and nor cells). Support of Trichoderma cells resulted further higher increase in viable cell number after 2 weeks, and the number was highest in the soil supported by T. reesei NBRC 31137 $\left(1.1 \times 10^{7}\right.$ cells $\left./ g\right)$. This means that microorganisms naturally habitat in soil, as well as bacidiomyces cells supported exogenously, proliferate well by support of YP medium constituent and involved in biodegradation of paperboard in soil. On the other hand, the viable cell numbers after 4 weeks were similar to those after 2 weeks on all experimental runs and were $3-4.5 \times 10^{6}$ cells/g.

As a conclusion, it was demonstrated here that immersion of Trichoderma cells enhanced the degradation rate of paperboard in soil, associated with nutritional elements for their growth. As paperboard supported by T. reesei strains NBRC 31137 and NBRC 31327 showed different degradation rates, we could control biodegradability by selecting microorganism to be supported. Otherwise the paperboard pot for seeding and transplantation have been kept their shape in the soil and would inhibit primary growth of plant root. While by quick degradation of pot by support of the basidiomyces, plant root would be able to grow faster. We confirmed that paperboard cup supported by $T$. reesei strains NBRC 31137 did not cause any inhibitory effect in germination of seed and initial growth of Komatsuna (Brassica camperstris var. peruviridis) (data not shown). $T$. reese $i$ and $T$. viride are recognized as safe to human (Nevalainen et al., 1994). In addition cellulolytic enzymes from the microorganisms have reported to show inhibitory effect to plant-pathgenic fungus (Picard et al., 2000). These properties would be rather favorable to cultivation of plants (Turoczi et al., 1996). Further investigation on effect of these microorganisms on growth of plant should be done for long term cultivation. 


\section{REFERENCES}

Consonni, S., M. Giugliano, and M. Grosso 2005 Alternative strategies for energy recovery from municipal solid waste. Part B: Emission and cost estimates, Waste Manage 25: 137-148

Gaint S, A. Pandey, K. Lata 2005 Biodegradation study of crop residues as affected by exogenous inorganic nitrogen and fungal inoculants $J$ Basic Microbiol 45: 301-311

Lo C.M., Q. Zhang, P. Lee, L.K. Ju (2005) Cellulase production by Trichoderma reesei using sawdust hydrolysate. Appl Biochem Biotechnol 121-124: 561-573

Nevalainen H, P. Suominen, K. Taimisto 1994 On the safety of Trichoderma reesei. J Biotechnol. 37(3): 193-200

Picard K, Y. Tirilly, N. Benhamou 2000 Cytological Effects of Cellulases in the Parasitism of Phytophthora parasitica by Pythium oligandrum, Appl Environ Microbiol 66(10): 4305-4314
Sakai K, H. Kawano, A. Fujii, Y. Iwami, M. Wakayama, M. Moriguchi 2001 Isolation of a Thermophilic Poly-L-lactide Degrading Bacterium from Compost and Its Enzymatic Characterization J Biosci Bioeng, 92: 298-300

Sakai K, M. Taniguchi, S. Miura, H. Ohara, T. Matsumoto, Y. Shirai 2003 Making Plastics from Garbage: A Novel Process for Poly-L-lactate Production from Municipal Food Waste, $J$ Indust Ecol 7: 63-74

Tan, H., and H. Khoo 2005 Life cycle assessment of EPS and CPB inserts: design considerations and end of life scenarios. $J$ Environ Manage 74: 195-205

Turoczi G, C. Fekete, Z. Kerenyi , R. Nagy , A. Pomazi, Horn 1996 Biological and molecular characterisation of potential biocontrol strains of Trichoderma. J Basic Microbiol 36(1): 63-72

Wyk J. P. H and M. Mohulatsi 2003 Biodegradation of wastepaper by cellulase from Trichoderma viride. Bioresour Technol. $\mathbf{8 6}(1)$ : $21-23$ 